\title{
Actions: ACRL Board of Directors, February 1994
}

\section{Highlights of the ACRL Board of Directors' Midwinter meetings}

$\mathbf{T}$ he Board of Directors of the Association of College and Research Libraries met twice during the Midwinter Meeting in Los Angeles on February 5 and February 8, 1994. Highlights of their meetings are as follows:

Established the English and American Literature Section. This will bring the total number of ACRL sections to 17.

\section{Established the Medium-Sized Libraries Discussion Group. This discussion group will deal with issues of interest to libraries that are typically grouped in the Carnegie Foundation's Classification of Institutions of Higher Educa- tion of "Comprehensive Universities and Col- leges, Type 1." The new group was formed as a result of a recommendation by a joint ULS and CLS Committee to Study the Organizational Juxtaposition of the 'Medium-Sized' College Li- brary within the ACRL Structure.}

Retained policy on conference and preconference registration fee requirements for program planners and established a task force to research the issue and make recommendations on the existing ACRL policy.

Funded the distribution of "Standards for Ethical Conduct of Rare Book, Manuscript, and Special Collections Librarians, with Guidelines for Institutional Practice in Support of the Standards, 2nd edition."

Approved two 1995 preconferences. LPSS will host a preconference on legal reference for non-law librarians; and RBMS will host its 36th preconference entitled "Collecting Cultures: The Politics and Practice of Building Special Collections."
Accepted the final report from the Image Task Force and instructed the Executive Committee to inform the Board on how it should respond to the recommendations at its meetings during the 1994 Annual Conference in Miami.

Established an Intellectual Freedom Committee. The Intellectual Freedom Task Force recommended the establishment of a standing committee of the Board because of the challenges to intellectual freedom in academe in such areas as access to collections and information, electronic networks, exhibits, sources of funds, and speech.

\section{Approved the College Library Section's Pro} posal to the Council on Library Resources for $\$ 22,600$ to fund the continuation of the College Library Directors Mentor Program.

Approved amendment to the ECLSS Bylaws that allows the secretary to serve as archivist-

\section{ACRL leaders address future}

Over 80 ACRL leaders participated in a half-day planning session during the Midwinter Meeting that was organized by the ACRL Board of Directors and facilitated by Maureen Sullivan. The following were identified as areas in which ACRL should be positioned: technology, visibility within higher education, leadership in the library and information environment, diversity, communications and networking, and library education and professional development.

A summary of input will be compiled and circulated to all participants while the ACRL Executive Committee and Board develop a strategy for addressing these issues. 
elect and archivist and to add the chair of the discussion group to the ECLSS Executive Committee.

\section{Endorsed the "Principles for} the Development of the $\mathrm{Na}$ tional Information Infrastructure" with the recommendation that the word "gender" be added to item \#1 under "First Amendment and Intellectual Freedom Principle."

\section{Endorsed four other resolu-} tions upon the recommendation of the Government Relations Committee. The resolutions were in support of LSCA reauthorization, HEA II appropriation, the Elementary and Secondary School Library Media Act, and for adequate funding for the Library of Congress.

\section{Approved the ACRL "Guidelines on the Se-} lection of General Collection Materials for Transfer to Special Collections," 2nd ed., and rescinded the 1988 edition. The 2 nd edition appeared in the December 1993 issue of CERL News.

\section{Approved the "ALA/SAA Joint Statement on} Access Guidelines for Access to Original Research Materials." The approved version of these guidelines, which appeared in the December 1993 CERL News was developed jointly by
RBMS and the Society for American Archivists and replaces the 1978 Joint Statement.

Approved a process for rescinding the "Guidelines on Manuscripts and Archives" upon the recommendation of the Standards and Accreditation Committee and RBMS because the 1977 guidelines contain contradictory and dated information.

Approved the 1995 preliminary budget which will be submitted to ALA for review by COPES. ( $E d$. note: Final approval will be made at the Tuesday afternoon meeting of the ACRL Board of Directors at the 1994 ALA Annual Conference in Miami.)

Changed the name and charge of the Audiovisual Committee at the request of that committee. The committee will now be known as the ACRL Media Resources Committee.

Approved an additional $\mathbf{\$ 2 5 , 0 0 0}$ for the Initiative Fund for FY1994. This brings to $\$ 35,000$ the total amount in the fund. ACRL units were notified of the increase in the fund; the application deadline was extended until March 25,1994 . The competitive process awards funding for new initiatives to ACRL units.

\section{ULS business meeting highlights}

Topics for the University Libraries Section's committees and executive committee at the ALA Midwinter Meeting in Los Angeles centered on the ALA Annual Conference in Miami and ACRL's National Conference in Pittsburgh in 1995.

Be sure to catch the program planned for ULS in Miami, 2:00-4:00 p.m. on Saturday, June 25. "Networking for Leadership: A Mosaic of Opportunities and Challenges for Campus Leadership" will feature speakers who have accepted the challenge on campuses across the country. Don't miss it!
Although plans are not complete, there are going to be some interesting panels and programs with an ACRL/ULS focus in Pittsburgh. Stay tuned to see what we will come up with.

Plans for the future offer some hot topics, new standards, and a continuing effort to make all members of ULS aware of the activities and discussions of the section. Stay tuned for discussion groups on the human face of organizational change, accreditation standards, research, technological change-in short, all of the topics that affect the lives of university librarians.-Mary Munroe, Geongia State University 


\section{ULS discusses virtual libraries and publishing}

\section{Changing organizational structures}

The University Library Section's Current Topics Discussion Group presented "Re-engineering the Library for the 90's and Beyond: Changing Organizational Structures and Staffing Patterns for the Virtual Library" during the ALA Midwinter Meeting. Arnold Hirshon, Wright State University, described his experiences contracting out cataloging services. The benefits include: dramatic reduction in cataloging costs, faster turn-around time, elimination of backlogs, improved quality, and liberation of organizational thinking. Some lessons learned: establish your goals and whether they include improving quality of service or redeploying staff, concentrate on results rather than process; establish target savings and what will make it worthwhile for your organization; ensure that organizational disruption will be offset by the amount of money you save; and decide whose support you'll need.

Ralph Moon discussed the reorganization of the University of California-Berkeley Library. The goals were: to unify the organization of the newly connected Main and Undergraduate Libraries, provide centralized leadership, address staff shortages in public services, and position the library to take advantage of developing technologies. Some public services department head positions were eliminated, freeing staff for new roles and providing a direct line of communication between public services and library administration. Three new organizations were created within the library: 1) The Teaching Library; 2) Information Systems Instruction and Support, which provides instruction for staff, a network librarian, and a systems help desk; 3) Library Enterprises, which generates funds through entrepreneurial activities. Some disadvantages: dedicated staff saw their positions disappear, internal recruitment led to months of nonstop job shifting, and communication needed to be improved.

Kevin Long described the merging of reference and computing services at Rice University Library where staff were told by administration to become more efficient and provide better service with information tech- nology. Reengineering is defined as trying to find effective, quantitative ways to improve services, not reorganizing or flattening the organization just to do things differently. When charting a course for a goal remember: missteps will occur, keep the process interactive, and take what is good and leave the rest.Mary Munroe, Georgia State University

\section{Research and publishing tips}

ULS's Research and Publishing Discussion Group featured four speakers who reviewed the research and publications processes from different perspectives. They were: Barbara Moran, University of North Carolina; Charles Martell, California State University at Sacramento; James Neal, Indiana University; and Ann Dougherty, Mountainside Publishing.

Moran suggested that librarians enroll in a formal class on research methodologies if research and publication are required. Look for "research holes" in efforts to identify relevant topics, read the journals, and record ideas for possible research. Moreover, recall the application and importance of qualitative research (in addition to quantitative research).

Martell noted that timeliness of topics is important. Record ideas for potential research and think critically. Research includes the ability to: see or identify a specific problem, consider the problem from a critical perspective, and develop possible alternatives.

Neal discussed four categories of research: 1) basic; 2) applied; 3) reflection; and 4) "What I've done good." If a survey is distributed, do the statistical analysis. Identify a relevant topic. Literature reviews are important, correct grammar is essential, and enthusiastic writing adds to overall quality. Share the manuscript with colleagues (for critical feedback) prior to submitting it for publication.

Dougherty suggested that librarians examine the scope of the journals under consideration as well as the guidelines for authors. Submit the manuscript to one journal at a time, use a good printer, request critical feedback from colleagues before submitting for publication, check all references for accuracy, include a cover letter, and use the active tense.Don Frank, Harvard University 